AGRICULTURE AND BIOLOGY JOURNAL OF NORTH AMERICA

ISSN Print: 2151-7517, ISSN Online: 2151-7525, doi:10.5251/abjna.2012.3.9.340.344

(C) 2012, ScienceHuß, http://www.scihub.org/ABJNA

\title{
Field evaluation of three biopesticides for integrated management of major pests of tomato, Solanum lycopersicum L. in Sudan
}

\author{
H.A.F. El Shafie ${ }^{1, *}$ and B.A. Abdelraheem ${ }^{2}$ \\ ${ }^{1}$ Department of crop protection, University of Khartoum, 13314 Shambat, Khartoum, Sudan \\ ${ }^{2}$ Ministry of Agriculture, Department of extension, Khartoum State, Sudan \\ "Corresponding author's e-mail: elshafie62@yahoo.com
}

\begin{abstract}
Two field experiments were conducted at two different locations in Khartoum State, Sudan during the cropping season 2007/2008 to evaluate the efficacy of three biopesticides on the major insects of tomato, (Solanum lycopersicum L.). Treatments applied were NeemAzal ${ }^{\circledR}-\mathrm{T} / \mathrm{S}(2 \mathrm{~L} / \mathrm{ha})$, $\operatorname{XenTari}^{\circledR}(1 \mathrm{~kg} / \mathrm{ha})$, Spinosad ${ }^{\circledR}$ (2L/ha). Sumicidin ${ }^{\circledR} 20 \%$ EC was applied at a rate of $0.7 \mathrm{~L} / \mathrm{ha}$ for comparison. Major insect pests studied were whitefly, Bemisia tabaci; aphids, Aphis gossypii and African bollworm (ABW), Helicoverpa armigera. All treatments significantly reduced the populations of the test insect pests. NeemAzal proved to be nearly as effective as Sumicidin. Higher numbers of the green lacewing, Chrysoperla carnea (Steph.) were found in biopesticidestreated and control plots compared with fewer numbers in Sumicidin- treated plots. The per cent increase in yield was $32 \%, 31.2 \%, 25.3 \%$ and $20 \%$ in plots treated with NeemAzal, Sumicidin, Xen Tari and Spionsad respectively.
\end{abstract}

Keywords: Solanum lycopersicum, Spinosad, Bacillus thuringiensis, biopesticides, Bemisia tabaci, Aphis gossypii, Helicoverpa armigera

\section{INTRODUCTION}

In Sudan, growing of vegetables particularly tomato (Solanum lycopersicum L.) is increasing. The main areas of production are restricted to irrigated sector (Dabrowski et al. 1994). Polyphagous insect such as whitefly, aphids and African boll worm are considered as major pests inflicting economic damage on the crop which is mainly produced during winter (Binyanson, 1997). Frequent use of synthetic insecticides, to manage these pests, lead to a destabilization of the ecosystem as well as insect resistance (Dittrich et al. 1990). Biopesticides have the potential to help in the management of these pests as safe alternatives to synthetic insecticides (Schmutterer, 1995; Elshafie and Basedow, 2003; Lowery et al.1993; Basedow et al., 2002).bjective of this study was to evaluate the field efficacy of three biopesticides namely, neem, spinosad, and Bacillus thuringensis (Bt.) as alternatives to synthetic insecticides against the major pests in tomato.

\section{MATERIALS AND METHODS}

Study sites, land preparation and transplanting: The study took place during the cropping season $2006 / 2007$ using the tomato cultivar peto 111. Two field experiments were conducted at two different locations viz., the University of Khartoum demonstration farm (Top farm) and El-Silait farm. The former site is very close to the Nile River $(0.8 \mathrm{~km}$ away) and the latter is about $10 \mathrm{~km}$ far. The winter season lasts from November to march mostly at 21$29{ }^{\circ} \mathrm{C}$ and a minimum of $16{ }^{\circ} \mathrm{C}$. The soil at both locations is silty clay-loam with a $\mathrm{pH}$ ranging between7-8.3. Growing, fertilizing, weeding and irrigation (with Nile water, every 7 days) of tomato followed farmers' practice. Nitrogen was applied as urea at a rate of $240-300 \mathrm{~kg} / \mathrm{ha}$ in two applications, 3 weeks apart. The land was divided into plots $(5 \mathrm{~m}$ $x 5 \mathrm{~m}$ ) and wide ridges (1 meter) were made in each. Tomato seedlings were raised in the nursery and transplanted to the experimental plots after 45 days. The spacing between plants was $20 \mathrm{~cm}$ and planting was made on both sides of the ridge. 


\section{Test materials and application technique:}

NeemAzal ${ }^{\circledR}$-T/S, a commercial formulation, containing 1\% Azadirachtin A, produced by TrifolioM GmbH company Lahnau, Germany, was used at a rate of $2 \mathrm{~L} / \mathrm{ha}$. XenTari ${ }^{\circledR}$ was used, at a recommended rate of $1 \mathrm{~kg} / \mathrm{ha}$. The active ingredient in XenTari is a pure, potent strain of $B$. thuringiensis var. aizawai which composed of protein crystal and viable endospores. Xen Tari ${ }^{\circledR}$ is produced by Valent Bioscience Corporation, USA. Spinosad ${ }^{\circledR}$ is a neurotoxic compound produced through a fermentation process by the naturally occurring soil bacterium Saccaroplyspora spinosa (Salgado, et al. 1998). Spinosad ${ }^{\circledR}$ is produced by Dow AgroSciences. Sumicidin ${ }^{\circledR} 20 \%$ EC, a synthetic pyrethroid, produced by Sumitomo was included in the study for comparison. The test products were applied weekly (one month after transplanting) until the end of the season. The preparations, their active ingredients, rate and volume of application per hectare are shown in Table 1. All preparations were applied in ultra low volume spray using a rotating atomizer (ULVA- sprayer Micron, Sprayers Ltd. Bromyard, Herts, UK).

Table 1: The preparations, their active ingredients and their application rate used in the two experiments with ULVA+ Sprayer

\begin{tabular}{|l|l|c|c|}
\hline Preparation & Active ingredient & Rate of application/ha & Volume of spray $\left(\mathrm{H}_{2} \mathrm{O}\right) / \mathrm{ha}$ \\
\hline Xen Tari $^{\Theta}$ & Bacillus thuringiensis & $1 \mathrm{~kg}$ & $20 \mathrm{~L}$ \\
\hline Spinosad & $20 \mathrm{~L}$ \\
\hline $\begin{array}{l}\text { NeemAzal- } \\
\text { T/S }^{\Theta}\end{array}$ & Saccaroplyspora spinosa & $2 \mathrm{~L}$ & $20 \mathrm{~L}$ \\
\hline Sumicidin $^{\Theta}$ & Azadirachtin A & $2 \mathrm{~L}$ & $20 \mathrm{~L}$ \\
\hline
\end{tabular}

Experimental design and treatments: There were two experiments at two different locations. In each experiment, the design was a Randomized Complete Block (RCBD) consisting of five treatments replicated four times. The treatments were as follows: (i) XenTari $^{\circledR}(1 \mathrm{~kg} / \mathrm{ha})$, (ii) Spinosad ${ }^{\circledR}(2 \mathrm{~L} / \mathrm{ha})$, (iii) NeemAzal-T/S ${ }^{\circledR}$ (2L/ha), (iv) Sumicidin ${ }^{\circledR} 20 \%$ EC (0.7L/ha) and (v) Control (20 L of water/ha).

Evaluation of the test products: The following Parameters were used to judge the performance profile of the test products: (i) number of whitefly $/ 100$ leaves (ii) number of Aphid/100 plants, (iii) number of larvae /100 plants for African bollworm, (iv) number and percentage of damaged fruits $/ 100$ plants, (v) number of green lacewing larvae /100 plants, and (vi) yield of tomato (t/ha).

Assessment of insects' number and damage: Larvae of African bollworm, adult of whitefly, adults and nymphs of aphids and larvae of the aphid predator green lacewing were counted throughout the growing season. Groups of 10 plants were randomly selected at each of a minimum of 4 locations in every ridge in every plot (the plot contained 3 ridges). The assessment of insects were done by carefully examining 10 leaves which were selected randomly on each plant, three from the bottom, four from the middle and three from the top of the plant. The under surface of the leaves was given more attention for inspection and the average insect counts were taken thereafter. The larvae of African bollworm were found mostly on the top of the fruits. Counting of insects was done before 8 O'clock in the morning when the activity of the insects was still low. Total number of fruits in a randomly selected one square meter was counted in each plot. The average of three readings was taken and the percentage of damaged fruits was then calculated.

Harvesting: Harvesting was started on 15/4/2007 and continued to the $15^{\text {th }}$ of May 2007. Six pickings of fruits were carried out at an interval of 5 days.

Sampling was made by counting and weighing the fruits in $1 \mathrm{~m}^{2}$ (3 times) in every plot. The average of the three $\mathrm{m}^{2}$ was taken to represent the productivity per plot.

Statistical analysis: Treatments were arranged in a completely randomized block design and the data was statistically analyzed by ANOVA. Duncan's Multiple Range Test was used for means separation.

\section{RESULTS}

Table 2 revealed that almost all treatments evaluated in this study, significantly reduced the populations of whitefly, aphids, and African bollworm. NeemAzal proved to be nearly as effective as Sumicidin in controlling the three pests. The same trend of efficacy was observed for all treatments in the two locations. The treatments also significantly reduced the per cent of fruits damaged by the APW (Table 3). The efficacy of Xen Tari and Sumicidin was at par 
while Spinosad and NeemAzal were less effective in reducing fruit damage by the APW compared with Xen Tari and Sumicidin. Yields from plots treated with biopesticides (table 5) were not significantly different Higher number of the predator green lacewing Chrysoperla carnea (Steph.) (Neuroptera, Chrysopidae) occurred in plots treated with biopesticides and control (water treatment) with no significant difference among treatments (table 4). In plots treated with Sumicidin, predator numbers were significantly reduced. Fruits yield increased significantly in treated plots over untreated (control) plots (table 5). All botanicals and Sumicidin were at par, however, relatively more yield (t/ha) was registered with NeemAzal followed by Sumicidin, Xen Tari and Spinosad. The per cent increase in yield was $32 \%, 31.2 \%, 25.3 \%$ and $20 \%$ respectively.

Table 2: Effect of test biopesticides on the mean number of whitefly, Aphids, and African bollworm at two different locations, Top Farm and Elsilait Farm

\begin{tabular}{|c|c|c|c|c|c|c|}
\hline \multirow{3}{*}{ Treatment } & \multicolumn{6}{|c|}{ Number of insects per 100 plants (per 100 leaves in case of whitefly ) } \\
\hline & \multicolumn{3}{|c|}{ Top Farm } & \multicolumn{3}{|c|}{$\begin{array}{ll}\text { Elsilait Farm } \\
\end{array}$} \\
\hline & Whitefly & Aphids & $\begin{array}{l}\text { African } \\
\text { bollworm }\end{array}$ & Whitefly & Aphids & $\begin{array}{l}\text { African } \\
\text { bollworm }\end{array}$ \\
\hline Xen Tari $^{(\circledast)}$ & $230 \pm 122 \mathrm{a}$ & $3161 \pm 923$ a & $14 \pm 7 b$ & $\pm 274 a$ & $965 \pm 225 a$ & $18 \pm 5 b$ \\
\hline Spinosad $^{(B)}$ & $115 \pm 25 a$ & $1715 \pm 377 b$ & $9 \pm 5 b$ & $\pm 49 \mathrm{a}$ & $648 \pm 214 b$ & $26 \pm 7 b$ \\
\hline NeemAzal ${ }^{(B)}$ & $76 \pm 34 b$ & $1755 \pm 557 b$ & $12 \pm 5 b$ & $360 \pm 104 \mathrm{~b}$ & $493 \pm 33 c$ & $29 \pm 8 c$ \\
\hline Sumicidin ${ }^{(B)}$ & $63 \pm 23 c$ & $1094 \pm 323 c$ & $19 \pm 10 b$ & $280 \pm 185 c$ & $485 \pm 213 c$ & $27 \pm 8 b$ \\
\hline Control & $333 \pm 137 a$ & $3211 \pm 1039 a$ & $104 \pm 75 a$ & $707 \pm 194 \mathrm{a}$ & $936 \pm 209 a$ & $100 \pm 10 \mathrm{a}$ \\
\hline
\end{tabular}

${ }^{*}$ Means $( \pm$ SD) based on 7 observations at weekly intervals

Figures in column followed by the same letters are not significantly different ( $p>0.05$, Duncan's Multiple Range Test).

Table 3: Percentage of damaged tomato fruits $/ \mathrm{m}^{2}$ caused by the larvae of the African bollworm in plots treated with biopesticides and synthetic insecticide ( Top Farm and Elsilait Farm)

\begin{tabular}{|c|c|c|}
\hline \multirow[t]{2}{*}{ Treatment } & \multicolumn{2}{|c|}{ Percentage of damaged fruits $/ \mathrm{m}^{2}$} \\
\hline & Top Farm & Elsilait Farm \\
\hline Xen Tari $\left.{ }^{(}\right)$ & $3.2 \pm 1.4 \mathrm{c}$ & $4.7 \pm 2.6 \mathrm{c}$ \\
\hline Spinosad $^{(2)}$ & $6.3 \pm 1.7 \mathrm{~b}$ & $7.1 \pm 2.5 \mathrm{~b}$ \\
\hline NeemAzal-T/S ${ }^{\circledR}$ & $5.9 \pm 3.7 b$ & $8.8 \pm 3.5 b$ \\
\hline Sumicidin $^{\circledR}$ & $1.9 \pm 1.0 \mathrm{c}$ & $6.7 \pm 3.0 c$ \\
\hline Control & $13.7 \pm 7.2 \mathrm{a}$ & $19.4 \pm 6.5 \mathrm{a}$ \\
\hline
\end{tabular}

Figures in column followed by the same letters are not significantly different ( $p>0.05$, Duncan's Multiple Range Test).

Table 4: The average number of green lacewing, Chrysoperla carnea larvae /100 plants observed on tomato treated with three biopesticides at Top farm and Silait

\begin{tabular}{|c|c|c|}
\hline \multirow[t]{2}{*}{ Treatment } & \multicolumn{2}{|c|}{ No. of green lacewing larvae/100 plants } \\
\hline & Top farm & Elsilait \\
\hline Xen Tari ${ }^{(B)}$ & $214 \pm 103 a$ & $126 \pm 31 a$ \\
\hline Spinosad $^{(\mathbb{R})}$ & $186 \pm 76 a$ & $104 \pm 19 a$ \\
\hline NeemAzal-T/S ${ }^{\circledR}$ & $194 \pm 113 a$ & $112 \pm 45 a$ \\
\hline Sumicidin $^{(}$ & $55 \pm 36 b$ & $37 \pm 7 b$ \\
\hline Control & $184 \pm 62 a$ & $106 \pm 13 a$ \\
\hline
\end{tabular}

Fiures in column followed by the same letters are not significantly different ( $p>0.05$, Duncan's Multiple Range Test). 
Agric. Biol. J. N. Am., 2012, 3(9): 340-344

Table 5: Yield (t/ha) of tomato treated with three biopesticides and one synthetic insecticide (Top Farm, Elsilait Farm).

\begin{tabular}{|c|c|c|}
\hline \multirow[t]{2}{*}{ Treatment } & \multicolumn{2}{|c|}{ Productivity t/ha } \\
\hline & Top Farm & $\begin{array}{ll}\text { Elsilait Farm } \\
\end{array}$ \\
\hline Xen Tari $\left.^{(}\right)$ & $95.5(25.3 \%)$ b & $82.4(28.8 \%)$ b \\
\hline Spinosad $^{(3)}$ & $91.4(20 \%) b$ & $78.6(22.8 \%) \mathrm{b}$ \\
\hline NeemAzal-T/S $\left.{ }^{(}\right)$ & $100.7(32 \%) b$ & $74.5(16.4 \%) \mathrm{b}$ \\
\hline Sumicidin $^{(}$ & $100.0(31.2 \%) b$ & $72.0(12.5 \%) b$ \\
\hline Control & $76.2 \mathrm{a}$ & $64.0 \mathrm{a}$ \\
\hline
\end{tabular}

Figures in column followed by the same letters are not significantly different ( $p>0.05$, Duncan's Multiple Range Test). Data in parenthesis indicate the per cent increase in yield compared with water control

\section{DISCUSSION}

The promising effect of the test biopesticides against major tomato pests which in turn increased the yield in the present investigation agreed with the finding of Mudathir and Basedow (2004). According to their findings neem formulations significantly reduced pest attack on tomato and increased yield. The yield of plot treated with NeemAzal was similar to those plots treated with synthetic chemicals. These findings are similar to the findings of Elshafie (2001) who reported that, the average yield of potato treated with NeemAzal and Sumicidin was 6.09, 6.35 and 3.36 for NeemAzal, Sumicidin and untreated Control respectively. This effect may be attributed to the repellent, antifeedant, and deterrence activities of neem and its safety to the beneficial insects. Neem oil used at a rate of $3 \mathrm{ml} / /$ water proved to be effective in controlling the whitefly, Bemisia tabaci on eggplants and okra in Ghana (Mochiah, et al. 2011). Xen Tari resulted in a significant mortality of the greater wax moth Galleria mellonella under laboratory conditions (Basedow et al. 2012). Spinosad demonstrates rapid contact and ingestion activity in insects which is unusual for a biological product (Salgado, et al. 1998). Tomato plant canopy is relatively dense depending on the plant density, variety, and fertilization. Spraying such plant with knapsack sprayer hinder good coverage due to the larger drop size of the spray which eventually leads to low efficacy of insecticides and botanicals are no exception. The spraying method used in this study with 20L/ha (ULV, very low volume) using ULV + sprayer was chosen mainly due to the small droplet size $(50-100 \mu \mathrm{m})$, in order to cover the whole canopy of the plant, and to reach the hidden insect pests at the lower side of the leaf and hence increasing the efficacy. The effect of NeemAzal on beneficial insects was equal, or same as the untreated control This result agreed with Jayaraj (1992) who reported in the laboratory using neem oils (50\% EC) against a number of parasitoids and predators of rice's pests and other crops, that neem oil were not harmful to these parasitoids and predators. Srivaster et al. (1985) reported that spraying of neem oils against sorghum aphid in the field trials at concentration of $0.1,0.2,0.5$ and $1 \%$ did not harm the larvae and adults of syrphid, and observed that there was no effect of NeemAzal-F on oviposition of coccinellids and syrphid was found after spraying. Neem and B.thuringiensis were reported to be safe for honey bees (Elbambi, 1992, Schmutterer, 1995). The topical acute activity of spinosad against honeybees is less than $1 \mu \mathrm{g}$ per bee which places spinosad in the highly toxic to bees category of the EPA. However, once residues have dried completely, toxicity of foraging bees is considered negligible (Mayer and Lunden, 1998). Side effects to stenophagous aphid antagonist, as observed during this study, are known for synthetic pyrethroid (Poehling and Dehne, 1986) and side effects have also been found in NeemAzal treated plots (Hermann et al. 1997, Elshafie and Basedow, 2003). These observations may explain the slide decrease in the number of green lacewing observed in the neem treated plots during this study. To be better able to evaluate the effects of biopesticides on beneficial, prey numbers per predator was taken into consideration. Cumulative prey number per individual predator were strongly reduced by NeemAzal sprays, but not in Sumicidintreated plots. Thus neem clearly affected the pests (prey) than the predator. The numerical relationship of the insect pests was altered in favor of the predator making it more likely that the biopesticides could effectively contribute to the reduction of pest attack on tomato without significant adverse effect on the natural enemies. This situation is likely to exist in stable ecosystem in the absence or less use of synthetic insecticides. Thus, biopesticides under investigation could be effectively used as pest management option in production of organic tomato 
to reduce pest populations below economic threshold and increase yield.

\section{REFERENCES}

Basedow, Th., Elshafie, H.A.F., Abo-Elsaad, M.M. and AIAjlan, A.M. 2012. Evaluation of Bacillus thuringiensis aizawai and neem for controlling the larvae of the greater wax moth, Galleria mellonella (Lepidoptera: Pyralidae). International journal of agriculture and biology. 14 (4): 629-632.

Basedow, Th., Ossiewatsch, H.R., Bernal Vega, J.A. Kollman, S., Elshafie, H.A.F., Nicol, C.M.Y. 2002. Control of aphids and whiteflies (Homoptera, Aphididae and Aleyrodidae) with different neem preparations in laboratory, greenhouse and field: effects and limitations. J. plant diseases and protection, 109, 612-623.

Binyanson, S.A. 1997. Comparison of three methods for establishing economic threshold levels for Jacobiasca lybica (de Berg) on eggplant. Ph.D. Thesis, University of Khartoum, Sudan.

Dabrowski, Z.T., Alsaffar, A.A., Abdelrahman, A.A., 1994. Integrated pest management on vegetable crops in the Sudan, development and implementation strategy. In: Dabrowski, Z.T. (Ed.). integrated vegetable crop management in the Sudan. ICIPE Science Press, Nairobi, Kenya, (ISBN 92906440871), pp.24-32.

Dittrich, V., Ernst, G.H. Ruesch, O., Uk, S., 1990. Resistance mechanisms in sweet potato whitefly (Homoptera, Aleyrodidae) population from Sudan, Turkey, Guatemala and Nicaragua. J. Econom. Entomol. 83, 1665-1670.

Elbambi M. A. (1992). The effect of bacterial pesticides formulation Bacillus thuringiensis on honey bees and greater, lesser wax moth . Arab J.of plant protection, 10:1, p 85. M: 49 .

Elshafie, H.A.F., Basedow, Th. 2003. The efficacy of different neem preparations for the control of insects damaging potatoes and eggplants in the Sudan. Crop protection, 22, 1015-1021.

Hermann, P., Zebitz, C.P.W. Kienzle, J. 1997. Effect of different NeemAzal formulations on larvae of the green lacewing Chrysoperla carnea (Steph.) (Neuroptera, Chrysopidae) in laboratory and semi-field, In: Kleebeg, H., Zebitz, C.P.W. (Eds.). Practice oriented results on use and production neem ingredients and pheromones. Proceeding of the fifth workshop, Wetzlar, Germany, pp.183-188.

Jayaraj S. (1992). Studied on IPM in rice-based cropping systems with emphasis on use of botanicals their safety, and socio-economic consideration. proc. Final workshop. Botanical pest control project phrase 2. IRRI, Los Banos, Philippines. 63-78.

Lowery, D.T., Isman, M.B., Brad, N.L. 1993. Laboratory and field evaluation of neem for the control of aphids (Homoptera: Aphididae). J.Econom. Entomol. 86, 864870.

Mayer, D. F. and J.D. Lunden. (1998). Research Reports: 72nd Annual Western Orchard Pest \& Disease.

Mochiah, M.B., Banful, B., Fening, K.N., Amoabeng, B.W., Offei Bonsu, K., Ekyem, S., Braimah, H. and OwusuAkyaw, M. 2011. Botanicals for the management of insect pests in organic vegetable production. Journal of Entomology and Nematology, 3(6), pp.85-97.

Mudathir, M. and Basedow, Th. 2003. Field experiments on the effects of neem products on pests and yield of okra Abelmoschus esculentus, Tomato, Lycopersicon esculentum and onion, Allium cepa in Sudan. Mitt. Deut. Ges. Allg. Angew. Entomol. 14: 407-410.

Poehling, H.M., Dehne, H.W. 1986. Mehrjeahrige Untesuchungen zur Bekaempfung von Getreideblattluesen in Winterweizen unter besonderer Beruecksichtigung direkter und indirekter Nebenwirkungen auf Nutzarthropoden. Meded.Fak. land bouwert. Gent 51 (3a), 1131-1145.

Salgado, V. L., J.J. Sheets, G. B. Watson, A. L. Schmidt. (1998). Studies on the mode of action of Spinosad: The internal effective concentration and the concentration dependence of neural excitation. Pesticide Biochemistry and Physiology. 60(2): 103110.

Schmutterer, H. (Ed.), 1995. The neem tree. Source of unique natural products for integrated pest management, medicine, industry and other purposes. Weinheim, New York, Basel, Cambridge, Tokyo (VCH).

Srivastara K.P; Pamar B.S. (1985). Evaluation of neem oil emulsifiable concentrate against sorghum Aphids. Neem News Letter 2 (1) 7-10. 